\title{
An Assessment of ICT Competencies of Public School Teachers: Basis for Community Extension Program
}

\author{
Las Johansen B. Caluza \\ Rommel L. Verecio \\ Devine Grace D. Funcion \\ Lowell A. Quisumbing \\ Micheline A. Gotardo \\ Mark Lester P. Laurente \\ Jeffrey C. Cinco \\ Vanessa Marmita \\ Leyte Normal University, \\ Tacloban City \\ Philippines
}

\begin{abstract}
This study aimed to assess the level of ICT competencies of public school teachers at San Jose Central Elementary School, Division of Tacloban City, Philippines. Descriptive survey method was used which involved a questionnaire, interviews, and observations. Sixty-two (62) teachers served as respondents. Results showed that most of the teachers have a basic knowledge on ICT and needs improvement. More trainings is hereby needed to the teachers for them to integrate ICT in teaching and other related task assigned to them so as to uplift and enhance the quality of education of the said elementary public school.
\end{abstract}

Keywords: Information Communication Technology, ICT Competencies, Assessment,Social Science, Descriptive Research, Philippines.

\section{INTRODUCTION}

Worldwide, Information and Communication Technology (ICT) are radically transforming the way we live. ICT is pervasive in our work, study and personal lives. Today's learners are growing up in a world characterized by technological change and innovation. Educators have recognized that there is a need to equip learners with the necessary skills and experiences that will enable them to become contributing members of the global community. Hence, it is generally believed that ICTs can empower teachers and learners, promote change and foster the development of the 21st century skills, but data to support these beliefs are still limited. On the other hand, ICTs is also believed to be able to contribute to the enhancement of learning in the world since these tools can play a role in reforming education systems, increasing access to pedagogical resources, improving the management of education and enhancing pedagogical techniques (Kuyoro Shade, O., Awodele, O., \& Okolie Samuel, O., 2012)However, the experience of introducing different ICTs in the classroom and other educational settings all over the world over the past several decades suggests that the full realization of the potential educational benefits of ICTs is not automatic. The effective integration of ICTs into the educational system is a complex, multifaceted process that involves not just technology-indeed, given enough initial capital, getting the technology is the easiest part! - but also curriculum and pedagogy, institutional readiness, teacher competencies, and long-term financing, among others (Tinio, 2003).ICT has the power to increase motivation and learner engagement and helps to develop life-long learning skills. As a powerful educational tool, ICT can facilitate the transformation of school education. But to make this happen it is vital to bring about the changes to the mind set and culture among teachers, administrators, parents and students; the way in which the curriculum is designed and delivered and how students are currently assessed. Thus, harnessing ICT continues be an important challenge to educators. The Philippine Government has shown serious commitment to ICT in education by announcing a series of initiatives to apply ICT in teaching and learning. These were aligned to the Millennium Development Goals and the Education For All movements. They have provided a global policy environment for the directions and nature of interventions towards the achievement of improved access to and quality of basic education. Other key policy documents have identified the need for ICT reform within the education sector and these have resulted in more prioritizing from regions, schools and teachers regarding the incorporation of ICT into the education system, San Diego, Cecilia. (2012).The San Jose Central Elementary 
School in the Division of Tacloban City is trying its best in providing and addressing solutions relative to this challenge, the use of ICT in the delivery of its educational system thereby equipping the necessary knowledge and skills of its teachers. Thus, through the initiative of the school principal, she requested the Leyte Normal University, Tacloban City, one of the state universities and colleges in the city of Tacloban and a Center for Teaching Excellence in Teacher Education in Region VIII, Philippines to conduct trainings of its teachers through a community extension program wherein it is one of the core functions of a higher education institution.

Thus, in response to this request and in accordance with Leyte Normal University community extension program of improving the quality of education, the IT and Computer Education Unit of the university is hereby committed to provide such opportunities for public school teachers in the field of information and communication technology. This is to equip and providing them the rights knowledge and skills in the integration of ICT in teaching in order to uplift and enhance the quality of education in the teaching and learning at San Jose Central Elementary School, Division of Tacloban City. Thus, it is on this premise that a needs assessment will be conducted to measure the level of ICT competencies of the teachers in order to design an ICT program suitable according to their needs.

\section{REVIEW OF RELATED LITERATURES}

The emergence of ICT in education has been so rapid that there exists a serious information gap regarding the actual infusion of technology in education. One force generating attention to the use of ICT in education is the growing need for lifelong learning. The two main rationales behind the lifelong learning concept are the rapid rise in the amount of information and the need for more frequent career changes. ICT can help implement lifelong learning by such activities as 'on-demand learning' and project based learning. It can also facilitate it by making learning 'anytime and anywhere', not just in classrooms, more feasible. It is becoming increasingly important in our daily lives and in our educational system. Therefore, there is a growing demand on educational institutions to use ICT to teach the skills and knowledge students need for the 21st century (Buabeng-Andoh, C. 2012). Studies reveal a number of factors which influence teachers' decisions to use ICT in the classroom: access to resources, quality of software and hardware, ease of use, incentives to change, support and collegiality in their school, school and national polices, commitment to professional learning and background in formal computer training (Mumtaz, S. 2000). The primary focal point in this article was on obstacles that educational practitioners perceive as major impediments for realizing their school based ICT objectives. Among the top 10 of obstacles were material as well as non-material conditions. The major obstacles were: lack of computers and lack of knowledge among teachers (Pelgrum, W. J. 2001).

According to Du Plessis, A., Paul, W.E.B.B. (2012) the barriers to ICT integration include limited resources, time constraints as a result of large class sizes, limited ICT related vision, lack of support from the Department of Education, not enough computer skilled teachers as well as a lack of rewards and incentives.

It is also evident that the following aspects are still in need of attention on an on-going basis:

- Training sessions

- School support visits

- Exposure to different ICT strategies

- Providing a web repository with ready-made ICT resources and lesson plans

- Helping teachers to obtain laptops and internet connections to be used at home in order to prepare forclassroom implementation

- Securing data projectors

- Securing netbooks that can be used in any classroom

- Providing opportunities for teachers to share their experiences, positive as well as negative (challenges)

According to Buabeng-Andoh, C. (2012) the rise of technologies has complicated its adoption and integration by teachers in the classroom. The effective integration of applied science into classroom practices poses a challenge to teachers than connecting computers to a network. For successful integration of ICT into teaching, the review has highlighted on factors that positively or negatively influence teachers' use of ICT. These are personal, institutional and technological components:

- Personal level, there are numerous elements that influence teachers' use of ICT. Teachers' feelings, knowledge and attitudes influence their usage of ICT in the educational activity.

- School stage, components such as support, financing, training and facilities influence teachers' adoption and integration of technologies into their classrooms. Teachers' professional development is a central component to successful integration of computers into classroom instruction

- Technological level, for successful adoption and integration of ICT into teaching, teachers must perceive the technology as more serious than previous practice; consistent with their existing values, past experiences and needs; ease to use, can be experimented with on a limited basis before reaching a decision to adopt and finally the results of the innovation are visible to others. 
According to Demetriadis, S., Barbas, et. .al. (2003) secondary school teachers' attitudes towards the innovation of ICT in the curriculum. Breeding efforts are mostly received by teachers, but consistent support and extensive training are necessary in order to consider themselves able for integrating ICT in their teaching methodologies. Teachers are interested in using ICT (a) to attain a better professional profile, and (b) to take vantage of any possible learning benefits offered by ICT but always inside the setting of the school culture. Then we experienced some open and communicative ways of ICT based teaching where school objectives encouraged, but also the assimilation of ICT tools into a traditional instructor-focused style of instruction. Teachers' attitude to adapt the ICT mode of usage is justified by research evidence that emphasize the situational character of cognition and expertness. Introducing ICT in schools is seen as starting a "negotiation" process where lower level goals may be modified to maintain what are perceived as goals of higher society.

There are two winners, according to Jones. (2004) there are clear evidence that ICT in teaching and learning has not transformed educational delivery in second-cycle schools in Ghana implying that teachers have not shifted from instructor- centered teaching to student-centered learning. The reasons for the low utilization of these hardware and software could be ascribed to lack of access to technological resources in the classroom and lack of teachers' training skills in the use of the equipment.

According to Korte, W. B., \& Hüsing, T. (2006) that ICT catch-up process necessary in schools in several European countries. This brings up to three aspects: firstly, the necessary increase in the number of computers shared between 100 pupils; secondly, the improvement of the type of internet access with the relocation to a broadband connection; thirdly, the use of ICT for education in classrooms. Strategy to focus more on primary schools when it adds up to the familiarization of students with ICT. But in three European countries - Germany, Luxembourg and Malta - are primary schools better equipped with ICT in terms of number of computers per 100 pupils. ICT investments in primary schools are probably not (thus far) seen as the top political objective at which to aim, with few exceptions.

According Teck, S. H., \& Lai, Y. L. (2011) that teachers and school administrators much ensure that computers in the access centers or laboratories are utilized for beneficial activities and not merely for recreational activities such as playing games or online chatting. Applications such as spreadsheet, database, word processing and introduction should be utilized for educational purposes as well searching for useful info via web browsing. Parents act as a significant function in furnishing the necessary facilities like computer and Internet access at home whenever possible to mold up and propel their children in adopting ICT in their everyday lives.

According to Al-Zaidiyeen, N. J., Mei, L. L., \& Fook, F. S. (2010) it examines the level of ICT use in and the attitudes of teachers towards the role of ICT for the educational purposes. The current study experiences led to the research about the economic consumption of information and communication technology in the process of educational activity and learning studies in Jordanian schools. The findings of this research have given more attention to the level of ICT use in order to increase and encourage the use of ICT tools in Jordanian schools in general and rural secondary schools in particular. The work contributed to the living physical structure of research regarding the use of ICT for educational purposes in developing countries. The study recommends that future researchers need to consider the in-depth qualitative studies such as classroom observations and in-depth interviews to investigate the level of ICT use by teachers.

\section{THEORETICAL FRAMEWORK}

Suliman, A. A. M., Raman, M., \& Hamid, R. A. (2007) states that Information and communication technologies (ICT) have developed to be one of the central building blocks of society. Countries are now considering the implementation of the fundamental abilities and ideas of ICT as an unavoidable part of education. Today, different new models of training in education are advancing because of the new opportunities brought about by the integration of ICT and specifically Web-Based Technologies into the educating and learning environment. The successful incorporation of such application depends to a huge degree on instructor's commonality and capacity with the IT learning environment. This study adopted as its theoretical underpinning to theNational ICT Competency Standard Framework (NICS) for teachers developed by the National Computer Center or NCC in the Philippines. The ICT Competency Standard Framework for teachers defines the competency outcomes, and the supporting knowledge and skills that are needed to utilize ICT in performing the job roles related to teaching in the Philippine setting. It provides the performance indicators to evaluate the level of knowledge andcompetence of teachers to apply ICT in the educational setting. This is very important considering that in today's learning environment, ICT is viewed as a change agent for education.In the past educational institutions have provided little choice for students in terms of the method and manner in which programs have been delivered. Students have typically been forced to accept what has been delivered and institutions have tended to be quite staid and traditional in terms of the delivery of their programs. ICT applications provide many options and choices and many institutions are now creating competitive edges for 
themselves through the choices they are offering students. These choices extend from when students can choose to learn to where they learn (Oliver, R. 2002).

The NICS structure is a wealth of information presented in a very compact form comprisingthe following elements:

- The Standard Title is a concise statement that describes the key area of competency.

- The Standard Descriptor is a brief description of the skills set covered by the standard.

- The Statements are described in outcome terms the key areas of competence covered by the standard. These are focused on performance and are demonstrable.

- The Indicators identify the actions an individual would normally take to perform the area of competence detailed in the relevant statement. These are specific evidence of the achievement of a defined skill or knowledge level or the competent completion of a task.

There are also different domains that are included within the framework of NICS, among these are:

1. DomainATechnology Operations and Concepts Competency Descriptors- This domain includes competencies related to technical operations andconcept, and productivity usage of various ICT tools like computers andcommunication devices as well as applications that are available on-line or off-line. Here the teachers will be tested to demonstrate knowledge and skills in basic computer operation and other information devices including basic troubleshooting and maintenance of computers. This includes the proficiency and skills in different productivity applications such as Word processing, Spreadsheets, Presentations and Antivirus softwares. It also focuses on the use of Internet applications to search, locate and retrieve information resources to support the learning environment.

2. Domain B Social and Ethical competency descriptors - This domain includes competencies related to social, ethical, legal and humanissues, and community linkage. This involvesunderstanding and observing legal practices in the use of technology like the legal implications of Software Licenses and Fair Use, Intellectual Property Rights, the Ethical use of technology in both personal and professional levels and respect for privacy and cyber etiquette, phone etiquette and similar use of technology. Plan, model and promote a safe and sound technology- supported learning environment.

3. Domain C Pedagogical competency descriptor - This domain includes competencies related to the use of technology in thefollowing components of an instruction process: 1) planning and designingeffective learning environments and experiences supported by technology; 2)implementing, facilitating and monitoring teaching and learning strategiesthat integrate a range of information and communication technologies topromote and enhance student learning; and 3) assessing and evaluatingstudent learning and performances.Apply and evaluate the usage of ICT integration in the teaching-learning process and use results to refine the design of learning.

4. Domain D is the Professional Competency descriptor - This domain includes competencies related to professional growth anddevelopment, research, innovation and collaboration. Proactively engage in exploring and learning new and emerging technologies. Identify educational sites and portals suitable to their subject area. Join online communities, subscribe to relevant mailing lists and online journals $\bullet$ Review new and existing software for education - Recommend useful and credible web sites to colleagues and Continuously evaluate and reflect on the use of technology in the profession for development and Conduct research on the use of technology in the classroom.In general, this set of competencies aims to prepare teachers to become users ofvarious ICTs to help both the students and themselves benefit from the technology. In the end, the prime benefits are: 1) access to information and knowledge resources, 2)communication and knowledge sharing, and 3) work efficiency.

\section{Objectives of the Study}

This study aimed to assess the level of Information Communication Technology (ICT) Competencies of Public School Teachers at San Jose Central Elementary School, Division of Tacloban City from SY 20152016.

Specifically, it sought answers to the following:

1. What is the profile of the teachers in terms of:

1.1 Gender

1.2 Highest Educational Attainment

1.3 Seminars/ Trainings Attended related to ICT

1.4 Access to the Internet

1.5 Technology Resources

2. What is the respondents' assessment on its level of competencies such as: 
2.1 Technology Operations and Concepts

2.2 Pedagogy

3. What ICT training programs can be proposed to enhance the competencies of the respondents?

\section{Research Design}

\section{METHODOLOGY}

The research method used by the researcher in this study was the descriptive method, which involved a questionnaire to assess the level of ICT competencies of the teachers at San Jose Central Elementary School, Division of Tacloban City from SY 2015-2016.

\section{Research Procedure}

The researcher sought permission through the School Principal of the San Jose Central Elementary School, Division of Tacloban City. This was done for the determination of respondents and for the distribution of the needs assessment survey questionnaires.

\section{Respondents of the Study}

This study was confined to all the teachers of San Jose Central Elementary School from school year 2015-2016. This includes a total of ninety (90) respondents involved in the study. The data are presented below:

Research Population
\begin{tabular}{|l|c|c|c|}
\hline SCHOOL YEAR & MALE & FEMALE & TOTAL \\
\hline $2015-2016$ & 34 & 56 & 90 \\
\hline
\end{tabular}

Further, out of 90 expected respondents there were only 62 who participated the survey, which is almost $69 \%$ of the entire population.

\section{Data Gathering Instruments}

The researcher used surveyed questionnaires as a main data gathering tool for this study. The instrument consists of two parts; the first part is composed of the demographic profile of the teachers and the second part focused on the ICT Competency assessment. Such instrument was adopted from the National ICT Competency Standard for Teachers.

The data collection was done through in-person distribution and were given enough time to think about the questions as stated on the questionnaire, thus producing more accurate information period.

\section{Statistical Treatment of Data}

Responses from the questionnaires were directly encoded and analyzed using Microsoft Excel application - descriptive statistics (frequency counts, percentages, and mean).

The mean of each item in the instrument was determined based on the following formula: $\mathrm{x}=\Sigma \mathrm{x} / \mathrm{n}$

where;

$$
\begin{aligned}
& \mathrm{x}=\text { weighted average } \\
& \mathrm{x}=\text { score of each respondent } \\
& \mathrm{n}=\text { number of responses }
\end{aligned}
$$

Figures and table presentation format followed the American Psychological Association Style (APA Table Guidelines, 2007).

\section{RESULTS AND DISCUSSIONS}

\section{Domain A: Technology Operations and Concepts}

Competency Descriptor:This domain includes competencies related to technical operations and concept, and productivity of various ICT tools like computers and communication devices as well as application available online or offline.

\section{Table 1.0}

Standard 1: Demonstrate knowledge and skills in basic computer operation and Other information devices, including basic troubleshooting and maintenance.

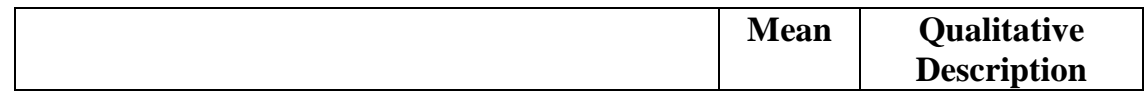




\begin{tabular}{|c|c|c|}
\hline $\begin{array}{l}\text { 1. Identify and define the functions of the } \\
\text { main components (i.e. monitor, CPU, } \\
\text { keyboard, mouse) of the computer }\end{array}$ & 2.7 & Proficient \\
\hline $\begin{array}{l}\text { 2. Identify and define the functions of the } \\
\text { computer peripherals (i.e. printer, scanner, } \\
\text { modem, digital camera, speaker, etc.) }\end{array}$ & 2.25 & Basic \\
\hline $\begin{array}{l}\text { 3. Properly connect main components, } \\
\text { configure peripherals and install drivers } \\
\text { when required }\end{array}$ & 2.15 & Basic \\
\hline $\begin{array}{l}\text { 4. Configure computer settings of various } \\
\text { software and hardware }\end{array}$ & 2.05 & Basic \\
\hline $\begin{array}{l}\text { 5. Understand the basic functions of the } \\
\text { operating system }\end{array}$ & 2.3 & Basic \\
\hline $\begin{array}{l}\text { 6. Organize and manage computer files, } \\
\text { folders, and directories }\end{array}$ & 2.45 & Basic \\
\hline $\begin{array}{l}\text { 7. Use storage devices (i.e. hard disk, } \\
\text { diskette, CD, flash memory, etc.) for } \\
\text { storing and sharing computer files. Create } \\
\text { back-ups for important files. }\end{array}$ & 2.45 & Basic \\
\hline $\begin{array}{l}\text { 8. Protect the computer from virus, spyware, } \\
\text { adware, malware, hackers, etc. }\end{array}$ & 2.2 & Basic \\
\hline $\begin{array}{l}\text { 9. Use online and offline help facilities for } \\
\text { troubleshooting, maintenance and update } \\
\text { of applications }\end{array}$ & 2 & Basic \\
\hline Grand Mean & 2.28 & Basic \\
\hline
\end{tabular}

The results in Table 1.0 shows that most of the respondents have basic knowledge relative to the skills in basic computer operations and other information devices. The respondents are proficient in identifying and defining the functions of the main components (i.e. monitor, CPU, keyboard, mouse) of the computer with a mean of 2.7. However, on the use of online and offline help facilities for troubleshooting, maintenance and update of applications, the result was lower with a mean of 2.0. Digital Literacy according to Glister (1997) is the ability to understand and use information in multiple formats from a wide range of sources when it is presented via computers. However, according to Meyers (2013), concerns about the lack of digital access have given way to concerns about being 'digitally illiterate', i.e., lacking the skills, understandings and practices required to successfully navigate the ever-changing digital landscape. This may be a factor why these indicators had the lowest rating. Jones (2004) found out that a very significant determinant of the teachers' levels of engagement in ICT is their level of confidence in using the technology. Teachers who have little or no confidence in using computers in their work will try to avoid them altogether (Jones, 2004: see Dawes, 2000; Larner and Timberlake, 1995; Russell and Bradley, 1997.). Another factor could be yes, the level of access to ICT is significant in determining levels of use of ICT by teachers (Mumtaz, 2000). Access to ICT infrastructure and resources in schools is a necessary condition to the integration of ICT in education (Plomp et. al., 2009). Yildrim (2007) found in a study that access to technology resources is one of the effective ways to teachers' pedagogical use of ICT in teaching. It is, therefore, important that teachers should have access to computers, the internet, hardware and software to increase their knowledge in ICT. Another factor could be the barriers to resources. Barriers are defined as any factor preventing or restricting teachers' use of technology in the classroom (Brinkerhoff, J. 2006: see Becta, 2003; Ertmer, 1999).

Table 2.0

Standard 2: Use Appropriate office and teaching productivity tools

\begin{tabular}{|l|c|c|}
\hline \multicolumn{1}{|c|}{ Standard 2: Use Appropriate office and teaching productivity tools } \\
\hline $\begin{array}{l}\text { Mean } \\
\text { images }\end{array}$ & $\begin{array}{c}\text { Qualitative } \\
\text { Description }\end{array}$ \\
\hline 11. Format text, control margins, layout, and tables & 2.65 & Proficient \\
\hline $\begin{array}{l}\text { 12. Print, store and retrieve text documents from a } \\
\text { word processor }\end{array}$ & 2.68 & Proficient \\
\hline $\begin{array}{l}\text { 13. Use a calculation spreadsheet to enter data, sort } \\
\text { data and format cells into Tables }\end{array}$ & 2.2 & Basic \\
\hline 14. Make computation, use formula and create graphs & 2 & Basic \\
\hline
\end{tabular}




\begin{tabular}{|c|c|c|}
\hline using spreadsheets & & \\
\hline $\begin{array}{l}\text { 15. Print and store data tables using a spreadsheet } \\
\text { application }\end{array}$ & 2 & Basic \\
\hline $\begin{array}{l}\text { 16. Use a presentation package to add text and } \\
\text { sequence a presentation }\end{array}$ & 2.2 & Basic \\
\hline $\begin{array}{l}\text { 17. Enhance slide presentations by adding sound, } \\
\text { customizing animation and inserting images }\end{array}$ & 2.1 & Basic \\
\hline $\begin{array}{l}\text { 18. Print presentation handouts and store slide } \\
\text { presentations }\end{array}$ & 2.2 & Basic \\
\hline $\begin{array}{l}\text { 19. Make effective class presentations using the slides } \\
\text { and LCD projector }\end{array}$ & 2.1 & Basic \\
\hline $\begin{array}{l}\text { 20. To acquire digital images and other media from } \\
\text { web sites, } C D \text {, flash drives, etc. }\end{array}$ & 2 & Basic \\
\hline $\begin{array}{l}\text { 21. Crop, scale, color correct and enhance digital } \\
\text { images }\end{array}$ & 2.26 & Basic \\
\hline $\begin{array}{l}\text { 22. Play various media files using appropriate media } \\
\text { players }\end{array}$ & 2.15 & Basic \\
\hline $\begin{array}{l}\text { 23. Stitch together video footages and soundtracks and } \\
\text { add simple enhancements - transitions, titles, etc. }\end{array}$ & 1.95 & Basic \\
\hline $\begin{array}{l}\text { 24. Attach and configure scanners, cameras, cell } \\
\text { phones to acquire digital images }\end{array}$ & 2.1 & Basic \\
\hline $\begin{array}{l}\text { 25. Store digital images using optical media (CD, } \\
\text { DVD, flash disk) and online repositories }\end{array}$ & 2.05 & Basic \\
\hline Grand Mean & 2.21 & Basic \\
\hline
\end{tabular}

Table 2.0 shows that most of the respondents have knowledge on the use of appropriate office and teaching productivity tools. However, it is noted that the respondents rated stitching together video footages and soundtracks and add simple enhancements - transitions, titles, etc. at the lowest with a mean of 1.95. This refers to the respondents' competence in using computer applications. Van Braak et al. (2004) defined computer competence as being able to handle a wide range of varying computer applications for various purposes. Research has shown that teachers require an expert in technology to show them the way to integrate ICT to facilitate students' learning (Plair, 2008). Similarly, Lawless \& Pellegrino (2007) stated that educators who integrate technology with new teaching practices gained through professional training can transform the performance of the students. Teachers when given time to practice with the technology, learn, share and collaborate with peer, it is likely that they will integrate the technology into their teaching (Buabeng-Andoh, C., 2012).

Table 3.0

Standard 3: Understand and effectively use the Internet and network applications and resources

\begin{tabular}{|l|c|c|}
\hline & Mean & $\begin{array}{c}\text { Qualitative } \\
\text { Description }\end{array}$ \\
\hline 26. Connect to the internet via dial-up or LAN & 2.4 & Basic \\
\hline $\begin{array}{l}\text { 27. Configure and use Web browsers and Help } \\
\text { applications }\end{array}$ & 2.15 & Basic \\
\hline $\begin{array}{l}\text { 28. Send and receive emails with attachments, } \\
\text { manage emails and use LAN and Web-based } \\
\text { mail servers }\end{array}$ & 2.1 & Basic \\
\hline $\begin{array}{l}\text { 29. Effectively use synchronous and asynchronous } \\
\text { web-based communication tools like instant } \\
\text { messengers, voice, and teleconferencing }\end{array}$ & 2.1 & Basic \\
\hline $\begin{array}{l}\text { 30. Connect and use shared printers, shared folders } \\
\text { and other devices within a network. }\end{array}$ & 1.9 & Basic \\
\hline $\begin{array}{l}\text { 31. Effectively use search engines, web directories, } \\
\text { and bookmarks. }\end{array}$ & 2 & Basic \\
\hline $\begin{array}{l}\text { 32. Download and install relevant applications } \\
\text { including freeware, shareware, updates, patches, } \\
\text { viewers, and support applications. }\end{array}$ & 2.05 & Basic \\
\hline Grand Mean & $\mathbf{2 . 1}$ & Basic \\
\hline
\end{tabular}


The internet has quite grown since it was first introduced. With only 400 million internet users globally in the year 2000, it has now reached 3.2 billion last 2015 (The International Telecommunication Union, 2015). The Philippines has seen quite a number of milestones in this endeavor, all of which started in 21 years ago on March 29, 1994 (DOST, 2016). The percentage of individuals using the internet in the Philippines have grown tremendously from $1.98 \%$ in 2000 to $40.70 \%$ in 2015 (ICT Data and Statistics, International Telecommunication Union). Access to the internet is not limited to the use of a personal computer, nowadays, there has been an increase of mobile users in the Philippines, from 6,454,359 million in 2000 to 120,255,00 million in 2015 (ICT Data and Statistics, International Telecommunication Union). This reflects on the results shown in Table 3.0 where Connecting to the internet via dial-up or LAN was rated the highest by the respondents. However, connecting and using shared printers, shared folders, and other devices within a network was rated the lowest with a mean of 1.9. This may be that the respondents do not frequently use these features when they use computers. According to Teo (2008), using computers more frequently and developing a variety of computer related skills and techniques increases one's knowledge of the computer as a whole. Another could be is the lack of technical support and/or training of the respondents. The lack of available technical support is also likely to lead to teachers avoiding ICT, for fear of a fault occurring that cannot be rectified and lessons being unsuccessful as a result (Becta, 2004: see Cuban, 1999; Preston et al.., 2000). In Preston et al. (2000) teachers felt that they had not had adequate training, particularly in their ability to solve technical problems and in understanding the basic workings of the technology.

Table 4.0

Standard 4: Demonstrate knowledge and skills in information and data management

\begin{tabular}{|l|c|c|}
\hline & Mean & $\begin{array}{c}\text { Qualitative } \\
\text { Description }\end{array}$ \\
\hline $\begin{array}{l}\text { 33. Effectively use search engines, directories, } \\
\text { crawlers and agents to locate information sources }\end{array}$ & 2.05 & Basic \\
\hline $\begin{array}{l}\text { 34. Search and collect textual and non-textual } \\
\text { information from online and offline sources }\end{array}$ & 2 & Basic \\
\hline $\begin{array}{l}\text { 35. Efficiently store and organize collected } \\
\text { information using directories, drives or databases }\end{array}$ & 2.1 & Basic \\
\hline $\begin{array}{l}\text { 36. Distribute, share, publish and print information } \\
\text { via print or web }\end{array}$ & 2 & Basic \\
\hline $\begin{array}{l}\text { 37. Properly acknowledge information sources - } \\
\text { online and offline }\end{array}$ & 2 & Basic \\
\hline
\end{tabular}

Research, as defined by Oxford Dictionaries, is the systematic investigation into and study of materials and sources in order to establish facts and reach new conclusions. Gathering sources for research is now relatively easy because of the Internet. However, the increasing use of the Internet by students is creating a serious problem (McCabe, D., 2005). Through his study, McCabe, D. (2005) found out that high school students who participated in focus groups said that teachers were not as Internet-savvy as their students and were unlikely to detect Internet Plagiarism. As defined by Oxford Dictionaries, plagiarism is the practice of taking someone else's work or ideas and passing them off as one's own. Merriam-Webster also defines plagiarism as the act of using another person's words or ideas without giving credit to the person. There are four types of academic plagiarism: (a) submission of a paper that was written by another student; (b) patchwriting - copying sentences from a source and mixing them with your own words without attribution; (c) failure to cite sources, and; (d) failure to use quotation marks (Baruchson-Arbib, et. al., 2004: see Howard, 2001). This literaturesupports on why teachers should know the proper way of doing citations both for online and offline sources to be able to guide their students on the proper way of gathering information.

\section{Domain C: Pedagogical Indicators}

Competency Descriptor: This domain includes competencies related to the use of technology in the following components of an instruction process: 1) planning and designing effective learning environments and experiences supported by technology; 2) implementing, facilitating and monitoring teaching and learning strategies that integrate a range of information and communication technologies to promote and enhance student learning; and 3) assessing and evaluating student learning and performances.

Table 5.0

Standard 1: Apply technology to develop students' higher order thinking skills and creativity

Mean $\quad$ Qualitative




\begin{tabular}{|l|c|c|}
\hline & Description \\
\hline $\begin{array}{l}\text { 38. Make students use databases, spreadsheets, concept } \\
\text { mapping tools and communication tools, etc. }\end{array}$ & 1.95 & Basic \\
\hline $\begin{array}{l}\text { 39. Encourage students to do data analysis, problem } \\
\text { solving, decision making and exchange of ideas }\end{array}$ & 2.05 & Basic \\
\hline Grand Mean & $\mathbf{2}$ & Basic \\
\hline
\end{tabular}

Item 38 in Table 5.0 yielded the lowest rating with a mean of 1.95 . This can be contributed to the following factors: availability and quality of computers for student to use and teacher's access to ICT resources. Mumtaz (2000) points out that evidence of very good practice in the use of ICT is invariably found in those schools that also have high-quality ICT resources, and that a lack of computers and software can seriously limit what teachers can do in the classroom with regard to the implementation of ICT. Becta (2004) mentioned in his paper that when discussing the issue of access to resources, it is important not only to think of the access teachers need in order to teach with ICT, but also to consider the need for teachers to have their own personal access to ICT, to allow them to plan and prepare lessons.

Table 6.0

Standard 2: Provide performance tasks that require students to locate and analyze information and use a variety of media to clearly communicate results

\begin{tabular}{|l|c|c|}
\hline & Mean & $\begin{array}{c}\text { Qualitative } \\
\text { Description }\end{array}$ \\
\hline $\begin{array}{l}\text { 40. Use appropriately slide presentations, videos, audio } \\
\text { and other media in the classroom }\end{array}$ & 2.25 & Basic \\
\hline $\begin{array}{l}\text { 41. Teach students to use various multimedia materials } \\
\text { for the reports and class presentations }\end{array}$ & 1.95 & Basic \\
\hline Grand Mean & $\mathbf{2 . 1}$ & Basic \\
\hline
\end{tabular}

In an investigation done by Cajilig (2011), it was found out that according to some teachers, they preferred to engage the students in interactive activities, but this would require the latter to work on several computers but which were not available in the classrooms. When doing a PowerPoint presentation, the teachers would normally bring their own laptops to school. This is similar to the findings in Table 5.0 where the availability of ICT resources for students to use in schools are limited. Bonifacio (2013) stated that computers in Philippine schools are acquired mostly through purchases using school funds or through donations by the government and private groups for many public schools and not all elementary and high schools have their own computer lab.

Table 7.0

Standard 3: Conduct open and flexible learning environments where technology is used to support a variety of interactions among students, cooperative learning, and peer instruction

\begin{tabular}{|l|c|c|}
\hline & Mean & $\begin{array}{c}\text { Qualitative } \\
\text { Description }\end{array}$ \\
\hline $\begin{array}{l}\text { 42. Use various synchronous and asynchronous } \\
\text { communication tools (email, chat, white boards, } \\
\text { forum, blogs) }\end{array}$ & 2.3 & Basic \\
\hline $\begin{array}{l}\text { 43. To facilitate cooperative learning and exchange of } \\
\text { ideas and information }\end{array}$ & 2.2 & Basic \\
\hline Grand Mean & $\mathbf{2 . 2 5}$ & Basic \\
\hline
\end{tabular}

Johnson (1991) defined cooperative learning as the instructional use of small groups so that student work together to maximize their own and each other's learning. Slavin (1987) in his book further says that in cooperative learning students in each group are responsible not only for learning the material being taught in class but also for helping their groupmates learn. As the Internet grows the use of communication tools also grows with it. Communication within communities of education (students, tutors, moderators etc.) can be facilitated by the use of computer-mediated communication (CMC) systems (e.g. chat box, e-mail, newsgroups) (Veerman, et. al, 2001). December (1996) describes CMC as "the process by which people create, exchange, and perceive information using networked telecommunications that facilitate encoding, transmitting, and decoding messages". Further, as defined by Cacciagrano, et. al (2001), a communication is synchronous when sending and receiving information between a sender and a receiver are simultaneous events; a communication is asynchronous when sending and receiving information between a sender and a receiver do not necessarily 
happen at the same time instant. Teachers nowadays make use of CMC as one strategy in their teachings in which the results on Table 7.0 supports. According to UNESCO ICT Competency Standards for Teachers it is stated under the Knowledge Deepening Approach that teachers should be able to use network resources to help students collaborate, access information, and communicate with external experts to analyze and solve their selected problems. Teachers should also be able to use ICT to create and monitor individual and group student project plans.

Table 8.0

Standard 4: Evaluate usage of ICT integration in the teaching-learning process and use the results to refine the design of learning activities

\begin{tabular}{|l|c|c|}
\hline & Mean & $\begin{array}{c}\text { Qualitative } \\
\text { Description }\end{array}$ \\
\hline $\begin{array}{l}\text { 44. Design rubrics for assessing student performance in } \\
\text { the use of various technologies }\end{array}$ & 2.15 & Basic \\
\hline $\begin{array}{l}\text { 45. Use electronic means of administering quizzes and } \\
\text { examinations }\end{array}$ & 2.1 & Basic \\
\hline $\begin{array}{l}\text { 46. Analyze assessment data using spreadsheets and } \\
\text { statistical applications }\end{array}$ & 2.15 & Basic \\
\hline Grand Mean & $\mathbf{2 . 1 3}$ & Basic \\
\hline
\end{tabular}

Stevens et. al (2013) in their book defines a rubric as a scoring tool that lays out the specific expectations for an assignment. Additionally, rubrics can be used for grading a large variety of assignments and tasks: research papers, book critiques, discussion participation, laboratory reports, portfolios, group work, oral presentations, and more. The use of rubrics is also supported by the Department Education under DO 73, s. 2012 wherein rubrics are given for the assessment and rating of learning outcomes for the different levels of assessment. However, on the administration of the electronic means of quizzes and examinations who got the lowest mean score can be attributed again to the lack of facilities. These findings can be related to the findings in Table 5.0 wherein lack of ICT resources could be a factor.

Table 9.0

Standard 5: Use computers and other technologies to collect and communicate information to students, colleagues, parents, and others

\begin{tabular}{|l|c|c|}
\hline & Mean & $\begin{array}{l}\text { Qualitative } \\
\text { Description }\end{array}$ \\
\hline $\begin{array}{l}\text { 47. Use emails, group sites, blogs, etc. for disseminating } \\
\text { information directly to students, colleagues and } \\
\text { parents }\end{array}$ & 2.15 & Basic \\
\hline $\begin{array}{l}\text { 48. Use emails, group sites, blogs, etc. collect } \\
\text { information directly to students, colleagues and } \\
\text { parents }\end{array}$ & 2.05 & Basic \\
\hline
\end{tabular}

Social media nowadays is the popular method for communication. Social media is a communication mechanism that allows users to communicate with thousands, and perhaps billions, of individuals all over the world (Williams et al., 2012). According to the website Statista, as of the first quarter of 2016, Facebook had 1.65 billion monthly active users. Additionally, a close to 40 million people in the Philippines accessed social networks in 2015. The most popular social networks and mobile messenger apps were Facebook with a $45 \%$ reach among internet users, followed by Google+, Instagram, and Facebook messenger (Statista, 2016). However, though social media is vastly used by people nowadays, there are still a number of teachers and parents as well who prefers to communicate face to face. The Department of Education (2009) as a general policy under DO 54, s. 2009, the Revised Guidelines Governing Parents-Teachers Association (PTAs) at the school level mandates that "Every elementary and secondary school shall organize a Parents-Teachers Association (PTA) for the purpose of providing a forum for the discussion of issues and their solutions related to the total school program and to ensure the full cooperation of parents in the efficient implementation of such program."(DEPED, 2009). It is through the PTA meetings that teachers and parents get to fully discuss the performance of their children.

Table 10.0

Standard 6: Apply technology to facilitate a variety of appropriate assessment and evaluation strategies recognizing the diversity of learners 


\begin{tabular}{|c|c|c|}
\hline & Mean & $\begin{array}{l}\text { Qualitative } \\
\text { Description }\end{array}$ \\
\hline $\begin{array}{l}\text { 49. Explore the use of electronic assessment tools like } \\
\text { online testing, submission of projects via email or } \\
\text { online facilities }\end{array}$ & 2 & Basic \\
\hline $\begin{array}{l}\text { 50. Set up online databases or repositories of student } \\
\text { works }\end{array}$ & 1.75 & Digital Illiterate \\
\hline Grand Mean & 1.88 & Basic \\
\hline
\end{tabular}

Table 10.0 shows that setting up online databases or repositories of students' works got the lowest mean of 1.75. Turner (2005) listed 20 basic skills that all educators should have, one of which is the Database skills. This is also supported by Aduwa-Ogiegbaen (2009) in their study of Nigerian inservice teachers where he recommended that all inservice teachers should have a minimum proficiency in the use of a variety of software, including basic word processing, database, and spreadsheet functions. Both authors stated the importance of these skills that educators should have. Additionally, in UNESCO ICT Competency Standards for Teachers, it is stated under the Technology Literacy Approach, teachers must know basic hardware and software operations, as well as productivity applications software, a web browser, communications software, presentation software, and management applications.

\section{CONCLUSIONS RECOMMENDATION}

Results of the study clearly revealed that teachers have basic knowledge in ICT. However, this is not enough to say that teachers are already competent in ICT. Teachers need to be proficient in knowing where and when to use technology for teaching and other related tasks. Teachers' professional development is a key factor to successful integration of computers in classroom teaching (Buabeng-Andoh, C., 2012). It is then recommended that teachers undergo training that will help further enhance their computer skills and knowledge.

\section{REFERENCES:}

[1] A du Plessis, A., \& Paul, W. E. B. B. (2012). Teachers' perceptions about their own and their schools' readiness for computer implementation: A South African case study. TOJET: The Turkish Online Journal of Educational Technology, 11(3).

[2] Aduwa-Ogiegbaen, S. E. (2009). Nigerian inservice teachers' self-assessment in core technology competences and their professional development needs in ICT. Journal of Computing in Teacher Education,26(1), 17-28.

[3] Al-Zaidiyeen, N. J., Mei, L. L., \& Fook, F. S. (2010). Teachers' attitudes and levels of technology use in classrooms: The case of Jordan schools.International Education Studies, 3(2), 211.

[4] Baruchson-Arbib, S., \& Yaari, E. (2004). Printed versus Internet plagiarism: A study of students' perception. International Journal of Information Ethics, 1(6), 29-35.

[5] Becta. (2003). What the research says about barriers to the use of ICT in teaching. Retrieved from http://www.becta.org.uk/research/ictrn/

[6] Becta, A. (2004). review of the research literature on Barriers to the uptake of ict by teachersa. London, UK, BECTA) http://publications. becta. org. uk/display. cfm.

[7] Bonifacio, A. L. (2013). Developing Information Communication Technology (ICT) Curriculum Standards for K-12 Schools in the Philippines. Curriculum Studies.

[8] Brinkerhoff, J. (2006). Effects of a long-duration, professional development academy on technology skills, computer self-efficacy, and technology integration beliefs and practices. Journal of research on technology in education, 39(1), 22-43.

[9] Buabeng-Andoh, C. (2012). An exploration of teachers' skills, perceptions and practices of ICT in teaching and learning in the Ghanaian second-cycle schools. Contemporary Educational Technology, 3(1), 36-49.

[10] Cacciagrano, D., \& Corradini, F. (2001, October). On synchronous and asynchronous communication paradigms. In Italian Conference on Theoretical Computer Science (pp. 256-268). Springer Berlin Heidelberg.

[11] Cajilig, N. G. (2011). Integration of Information and Communication Technology in Mathematics Teaching in Metro Manila Public Secondary Schools. Education Quarterly, 67(1).

[12] Cuban, L. (1999). The technology puzzle. Education Week, 18 (43). http://www.edweek.org/ew/vol18/43cuban.h18

[13] Dawes, L. (2000). The National Grid for Learning and the professional development of teachers: outcomes of an opportunity for dialogue. $\mathrm{PhD}$ thesis. 
[14] December, J. (1996). What is Computer-mediated Communication? From http://www.december.com/john/study/cmc/what.html

[15] Demetriadis, S., Barbas, A., Molohides, A., Palaigeorgiou, G., Psillos, D., Vlahavas, I., ... \& Pombortsis, A. (2003). "Cultures in negotiation": teachers' acceptance/resistance attitudes considering the infusion of technology into schools. Computers \& Education, 41(1), 19-37.

[16] DEPED (2009).DO 54, s. 2009 - Revised Guidelines Governing Parents-Teachers Associations (PTAs) at the School Level. Retrieved from http://www.deped.gov.ph/orders/do-54-s-2009

[17] DEPED (2012). DO 73, s. 2012 -Guidelines on the Assessment and Rating of Learning Outcomes Under the K to 12 Basic Education Curriculum. Retrieved from http://www.deped.gov.ph/orders/do-73-s-2012

[18] DOST (2016). History of Internet in the Philippines. Retrieved from http://icto.dost.gov.ph/the-historyof-internet-in-the-philippines/

[19] Ertmer, P. (1999). Addressing first and second order barriers to change: Strategies for technology integration. Educational Technology Research and Development, 47(4) 47-61

[20] Gilster, P., \& Glister, P. (1997). Digital literacy. Wiley Computer Pub.

[21] Howard, R. M. (2001). Plagiarism: what should a teacher do?. Retrieved March 20, 2004 from http://wrthoward.syr.edu/Papers/CCCC2001.html

[22] International Telecommunication Union. (2015). ICT Facts and Figures - The World in 2015. ITU.

[23] Johnson, D. W. (1991). Cooperative Learning: Increasing College Faculty Instructional Productivity. ASHE-ERIC Higher Education Report No. 4, 1991. ASHE-ERIC Higher Education Reports, George Washington University, One Dupont Circle, Suite 630, Washington, DC 20036-1183.

[24] Jones, A. (2004). A review of the research literature on barriers to the uptake of ICT by teachers

[25] Korte, W. B., \& Hüsing, T. (2006). Benchmarking access and use of ICT in European schools 2006: Results from Head Teacher and A Classroom Teacher Surveys in 27 European countries. empirica, 1, 0.

[26] Kuyoro Shade, O., Awodele, O., \& Okolie Samuel, O. (2012). ICT: An Effective Tool in Human Development. International Journal of Humanities and Social Science, 2(7), 157-162.

[27] Larner, D., Timberlake L. (1995). Teachers with limited computer knowledge: variables affecting use and hints to increase use. The Curry School of Education, University of Virginia.

[28] Lawless, K., \& Pellegrino, J. (2007). Professional development in integrating technology into teaching and learning: Knowns, unknowns and ways to pursue better questions and answers. Review of Educational Research, vol. 77, no. 4, pp. 575-614.

[29] McCabe, D. (2005). Cheating: Why students do it and how we can help them stop. Guiding students from cheating and plagiarism to honesty and integrity: Strategies for change, 237-246.

[30] Meyers, E. M., Erickson, I., \& Small, R. V. (2013). Digital literacy and informal learning environments: an introduction. Learning, Media and Technology, 38(4), 355-367.

[31] Mumtaz, S. (2000). Factors affecting teachers' use of information and communications technology: a review of the literature. Journal of information technology for teacher education, 9(3), 319-342.

[32] Oliver, R. (2002). The role of ICT in higher education for the 21 st century: ICT as a change agent for education. Retrieved April, 14, 2007.

[33] Plair, S. (2008). Revamping professional development for technology integration

[34] Plomp, T., Anderson, R. E., Law, N., \& Quale, A. (Eds.). (2009). Cross-national information and communication technology: policies and practices in education. Charlotte, N.C.: Information Age Publishing.

[35] Preston, C., Cox, M., Cox, K. (2000). Teachers as innovators: an evaluation of the motivation of teachers to use Information and Communications Technology. MirandaNet

[36] Russell, G., Bradley, G. (1997). Teachers' computer anxiety: implications for professional development. Education and Information Technologies, 2 (1), pp.17-30.

[37] San Diego, Cecilia. (2012 December 10). ICT in Education. Retrieved from http://www.depedne.net/?page $=$ news \&action $=$ details \&code $01=A I 12100001$

[38] Slavin, R. E. (1987). Cooperative learning and the cooperative school.DOCUMENT RESUME EA O23 724 Brandt, Ronald S., Ed. Cooperative Learning and the Collaborative School: Readings from" Educational Leadership., 45, 2.

[39] Statista: The Statistics Portal (2016). Number of Facebook users in the Philippines from 2014 to 2019 (in millions). Retrieved from http://www.statista.com/statistics/490455/number-of-philippines-facebookusers/

[40] Stevens, D. D., \& Levi, A. J. (2013). Introduction to rubrics: An assessment tool to save grading time, convey effective feedback, and promote student learning. Stylus Publishing, LLC

[41] Suliman, A. A. M., Raman, M., \& Hamid, R. A. (2007). ICT for Higher Education in Sudan: Issues and Perspectives. Managing Worldwide Operations \& Communications with Information Technology. 
[42] Teck, S. H., \& Lai, Y. L. (2011). An empirical analysis of Malaysian pre-university students' ICT competency gender differences. International Journal of Network and Mobile Technologies, 2(1).

[43] Teo, T. (2008). Pre-service teachers' attitudes towards computer use: A Singapore survey. Australasian Journal of Educational Technology, 24(4), 413-424.

[44] Tinio, V. L. (2003). ICT in Education.

[45] Turner, L. (2005). 20 Technology Skills Every Educator Should Have. The Journal.

[46] UNESCO. ICT Competency Standards for Teachers. Retrieved from http://unesdoc.unesco.org/images/0015/001562/156207e.pdf

[47] Williams, D.L., Crittenden, V.L., Keo, T. and McCarty, P. (2012), "The use of social media: an exploratory study of uses among digital natives", Journal of Public Affairs, Vol. 12 No. 2, pp. 127-136.

[48] van Braak, J., Tondeur, J., \& Valcke, M. (2004). Explaining different types of computer use among primary school teachers. European Journal of Psychology of Education, 19(4), 407-422.

[49] Veerman, A., \& Veldhuis-Diermanse, E. (2001, March). Collaborative learning through computermediated communication in academic education. In Euro CSCL (pp. 625-632).

[50] Yildirim, S. (2007). "Current Utilization of ICT in Turkish Basic Education Schools: A Review of Teacher's ICT Use and Barriers to Integration". International Journal of Instructional Media, vol. 34, no.2, pp. 171-86. 